\title{
Lessons for the mining industry from non-mining landscape restoration experiences
}

\author{
P.H. Whitbread-Abrutat Wardell Armstrong International and Eden Project, UK
}

A.D. Kendle Eden Project, UK

N.J. Coppin Independent consultant, formerly Wardell Armstrong International, UK

\begin{abstract}
Mining is a temporary land use that can produce great economic value from a small physical footprint, although sometimes with an environmental and social footprint that can be devastated by the activity. Nevertheless, mining has the potential to create a foundation for real (sustainable) development in the locality and region around the mine.

In this paper, landscape restoration is defined as the improvement of degraded environments on a large scale that enhances ecological integrity while improving peoples' lives. There is a growing realisation in many parts of the world that only at a landscape level can restoration projects deliver the scale of environmental and socio-economic improvements that will contribute significantly to the provision of ecosystem services and the development of meaningful, long-term livelihood opportunities. This paper considers several world-class - yet non-mining - landscape restoration projects to extract signposts to good practice of relevance to the mining industry.

How a mine integrates with the surrounding environmental and socio-economic landscapes plays a large part in determining its post-closure success. Typically, mine operators are proficient at considering this connectivity from a supply chain perspective during the development and operational phases. But closure is often an afterthought, with the company focussed primarily on reducing the ongoing environmental and public health and safety risks of the site itself. Despite the exertions of accepted good practice, little thought onsite and in the wider corporate body is usually given to the ecological/ social/ economic possibilities engendered by the 'blank canvas' of the post-mining landscape and its environs. The connectivity mentioned previously is, arguably, most important at this stage in order to maximise the mine's success in terms of post-closure sustainability outcomes.
\end{abstract}

This paper reviews accepted good industry practice in mine closure, summarising the pertinent points and addressing its limitations, and considers how good practice can be improved when pertinent lessons are extracted from non-mining landscape restoration projects. The ultimate aim is to address the silo thinking that occurs within the industry and to encourage the dismantling of barriers between mining and other land use disciplines.

\section{Introduction}

Combating land degradation is one of global society's major environmental challenges; the erosion of the terrestrial resource (and its natural and social capital) directly affects the lives and futures of billions around the world (Nkonya, et al., 2011; Bai, et al., 2008; Millennium Ecosystem Assessment, 2005). Restoring degraded landscapes (and ecosystems) is a powerful way to rebuild ecological integrity and enhance the lives and livelihoods of people connected with them for the long term - a sustainability concept that is gradually gaining traction with the advent of major new ecosystem-focussed international initiatives such as the Commission on Ecosystem Management of the International Union for Conservation of Nature (IUCN) (Keith et al., 2013). 
Mining, like most human activities, inescapably causes environmental damage and can distort the social and economic structures of communities and societies (e.g., Lindberg et al., 2011; Kulkarni et al., 2011). Too often, mine closure activities have been and are insufficient to adequately reverse the environmental damage, and they leave behind communities unable to cope with the long-term after-effects of mining. Mine closure is commonly an afterthought, with the company focussed primarily on reducing environmental and public health and safety risks of the site itself. Despite the exertions of accepted good practice, little thought at the mine, in the wider corporate body or among stakeholders is usually given to the ecological/ social/ economic possibilities engendered by the 'blank canvas' post-mining landscape and its environs. The connectivity mentioned above is, arguably, most important at this stage in order to maximise the mine's success in terms of post-closure sustainability outcomes, because what happens at and after closure should be a key factor in determining how successful the mine has been in converting mineral assets to sustainable benefits to society.

This paper considers accepted good practice in mine closure in relation to the wider aims and expectations of landscape restoration. It addresses the limitations of current closure good practice and the opportunities engendered in the process of closing mines, as derived from an examination of non-mining landscape restoration projects. This paper is not intended as a formal, academic review of mine closure procedures but rather a discussion of approaches and practices in the light of knowledge gained from beyond the industry itself. The aim is to address the 'silo thinking' that can occur within the industry and to encourage the dismantling of barriers between mining and other land use disciplines. The paper builds on the authors' combined 90-plus years of mine closure and landscape restoration experience, and its recommendations draw on case studies from around the world.

\title{
2 Limitations of current good practice
}

According to the World Bank:

\begin{abstract}
"Closure and post-closure activities should be considered as early in the planning and design stages as possible... A mine closure plan that incorporates both physical rehabilitation and socioeconomic considerations should be an integral part of the project life cycle and should be designed so that: Future public health and safety are not compromised; the after-use of the site is beneficial and sustainable to the affected communities in the long term; adverse socio-economic impacts are minimised and socio-economic benefits are maximised" (World Bank, 2007a).
\end{abstract}

In addition, it is expected that the plan should:
"Address beneficial future land use; be regularly updated and refined; include appropriate aftercare and continued monitoring of the site...; engage in some form of progressive restoration during operations; include contingencies for temporary suspension of activities and permanent early closure; [and] meet the following objectives for financial feasibility and physical/ chemical/ ecological integrity" (World Bank, 2007a).

Such guidelines support the Performance Standards on Environmental and Social Sustainability of the International Finance Corporation (IFC) (IFC, 2012a, b) and similar Performance Requirements from the European Bank for Reconstruction and Development (EBRD, 2008). Seventy-eight international financial bodies have officially adopted the Equator Principles - "a credit risk management framework for determining, assessing and managing environmental and social risk in project finance transactions" (Equator Principles, 2006) - that are underpinned by the IFC Performance Standards and the World Bank Group's Environmental, Health and Safety Guidelines, including the expectations for mine closure good practice (WBG, 2007b).

Such high-level processes and objectives are backed up by national legislation and more detailed guidance from a range of national and international stakeholders, some of the leading ones being the International Council on Mining and Metals' (ICMM's) Planning for Integrated Mine Closure: Toolkit (ICMM, 2008) and its Guidance Paper - Financial Assurance for Mine Closure and Reclamation (ICMM, 2006) and the Australian 
government's good-practice guidance documents on mine closure and completion and on mine rehabilitation (Australian Government, 2006a,b). The mining waste directive of the European Union (EU) aims to improve the treatment and management of mineral wastes by the mining industry in EU member states (EU, 2006) and is backed up by best practice guidance (EU, 2009). National and provincial jurisdictions in mining regions around the world generally also legislate for mine closure, based usually, as a minimum, on slope and ground stabilisation and revegetation.

Many multinational mining companies have developed their own corporate standards that apply across their operations wherever they occur. Rio Tinto's in-house Closure Standard provides clear guidance to corporate expectations for mine closure and is designed to accommodate leading practice from ICMM and others and to meet national regulatory requirements in the jurisdictions where the company operates (Rio Tinto, 2013). Similarly, Anglo American has developed an in-house Mine Closure Toolbox to enable it to apply closure good practice across all its operations to meet the company's own in-house performance standard (Anglo American, 2013).

So, considering the availability of closure good-practice guidance, corporate standards and legislation and planning, the question has to be asked: Why are mines still being poorly closed, leaving environmental problems and impacted communities?

\section{1 $\quad$ Financing closure}

Older working mines may have been operating since before the requirement for closure planning and financing, so may lack these. On long-life mines, the final operator may be different than the original, with lower environmental and social expectations. Also, a company acquiring an existing or brownfield asset will aim to protect itself from inherited liabilities, so these will often be excluded and passed to the state.

A closure fund must be available to the body that is undertaking the closure, which may not be the mining company itself. Thus the fund should be tangible and ring-fenced from the company's assets, not just a liability accrued on the balance sheet. The main costs and liabilities occur when an operation has declining revenue and is least able to fund them; so unless a cash fund has been accrued, or the operator has sufficient corporate resources, there will be no finance for closure. Similarly, a sudden fall in commodity prices can lead to a rapid decline in the solvency of the company and, therefore, unplanned abandonment. In these cases, the mine closure fund or guarantee has to be invoked, if there is one.

\section{$2.2 \quad$ Local communities and socio-economic development}

Assisting communities and alleviating socio-economic impacts should be at the heart of closure planning. In reality, most closure effort is expended in ensuring future public health and safety at best, with minimal long-term thinking applied to other community impacts, which is often limited to covering the site with vegetation for grazing. The socio-economic aspects are usually poorly considered, save some financial handouts for assisting with unemployment and one or two finite community projects. Most mines, when funded by international lenders, are required to produce community development plans (CDPs) aimed to ensure that some of the values won from the ground become embedded in local communities, but often the CDP process is detached from the closure planning process, the former often being reactive responding to local requests for 'things' (roads, schools, etc.) rather than pro-active - focussing on strengthening local institutions and building capacity, which are vital to ensuring post-mining community viability (World Bank, 2011).

Many mines do not employ dedicated community engagement or development specialists; at best they expect an environmental manager or public relations officer to take on this role. In many instances the mine will need to restore the ecosystem services that a community uses and that it will need to use long after the mine has closed. Community development is tricky to get right but easy to get wrong, and it can negatively affect the company's and even the industry's social licence to operate. 


\subsection{Legislation and good-practice guidance and standards}

Despite the recent progress encouraged by national laws and regulation and by standards and goodpractice guidance, practice remains inadequate in many jurisdictions. Such commendable performance drivers can only be effective when other factors allow them to be, as many countries lack regulator capacity or corporate finance for closure, possess an inadequate planning system or poor company knowledge or are stymied by short-sighted attitudes. For reasons of culture, capacity or democracy, some regions may also lack an active civil society to oversee mining activities and act as a critical interface between company, government and community.

Much of the closure legislation, standards and guidance available focuses on limiting negative impacts with relatively little emphasis devoted to enhancing positive ones. The focus, too, of conventional closure practice on most mines is often geographically and psychologically confined to the site footprint and its immediate environs, despite the exhortations of good-practice initiatives.

\section{$2.4 \quad$ Skills, knowledge and attitudes}

Despite the plethora of regulation and initiatives, there is little step-by-step instruction to success, which ultimately derives from the application of experience and skills to be found in a diverse array of specialists. Although closure is a multi-disciplinary event it is often addressed by just one or two technical disciplines commonly a geotechnical engineer and an environmental scientist - maybe due to operator expediency in achieving the minimum legal closure requirement as cheaply as possible.

Such expediency is compounded by unfortunate attitudes commonly found in all the closure stakeholder groups - typically including innate distrust of environmental expertise among miners, environmental and social specialists unable to see positive opportunities in mining situations, a general unwillingness to learn from others' experiences and arrogance by all parties - as epitomised here in some recent comments to the authors:

"We are a mining company, not a closure company; we will just demolish the buildings and sell the scrap and move on" (director of a multinational mining company, Europe).

"There is nothing interesting happening in mine closure and post-mining regeneration in Latin America" (director of an environmental group, UK).

"Mine closure is not so important in this part of the world" (mining consultant, Kazakhstan).

Mines may operate in areas where there is little background ecological knowledge that can assist the closure and restoration process. Too often, it is assumed that a site can be easily restored simply by spreading soil - assuming it has been saved and appropriately stored - and reseeding or 'planting a few trees'. These approaches lack the intricate ecological/ horticultural knowledge to ensure success, and they leave the 'restored' landscape in a poor state of recovery, with less opportunity to be derived for local communities. Commonly, insufficient company effort is expended on the necessary ecological restoration research up-front that can save money and reputations in the long term.

The industry displays impressive lateral, collaborative and creative thinking when overcoming the obstacles to developing mines in remote areas and in physically and politically challenging environments, but such thinking is generally not applied to closure. The 'silo thinking' found in all mining stakeholder groups discourages the exploration of parallel interests in other sectors, leading to an inability to learn from them and apply any new knowledge thus generated. 


\section{$3 \quad$ Extending good practice from non-mining landscape restoration projects}

\subsection{Rationale}

Examples of mine closure good practice are often used for self-promotion by one organisation or another, which can, on independent analysis, only partly meet the generic principles outlined in most closure plans and guidance. This paper premises that much can be learned from non-mining landscape restoration practices to address many of the mine closure limitations outlined above. Land is the common denominator across all kinds of land restoration activity, as opposed to the conventional view of considering the factors causing the disturbance. It is pertinent to look beyond the confines of the mining industry to other sectors to understand how common issues are addressed and seek transferable lessons.

Four case studies of different non-mining restoration projects are introduced below to support the analysis in this paper, although the thinking outlined herein has been synthesised from hundreds of diverse projects over many years. The case studies are more fully described in Whitbread-Abrutat (2012).

\subsection{Defining landscape restoration}

Landscape restoration is defined here as the improvement of degraded land on a large scale that rebuilds ecological integrity and enhances people's lives. This is deliberately broad in order to encompass a diverse range of ambitions, activities, scales, environments, societies and end uses. It adapts Maginnis and Jackson's (2007) definition of forest landscape restoration to non-forest landscapes and introduces the notion of scale. It extends the Society for Ecological Restoration International's definition of ecological restoration to include concepts of scale and landscape (as opposed to ecosystem) (SER, 2004), and reinforces the human element - as recognised by Hobbs and Norton (1996) and Hobbs and Harris (2001) in their syntheses of large-scale ecological restoration drivers. It was also informed by a comprehensive international survey on mining legacies for the ICMM-IUCN Dialogue on Mining and Biodiversity (Whitbread-Abrutat, 2008). Key aspects of the definition are that landscape restoration activities should:

- Improve degraded environments through rebuilding ecological integrity by reducing or reversing degradation pressure; reintroducing missing or declining biodiversity; connecting disconnected landscape elements; involving a mosaic of ecological habitats, communities, land uses and interest groups; ensuring that communities and habitats are enhanced by the restoration programme; and stimulating development of a self-sustaining system.

- Operate on a large (temporal/ areal) scale by recognising that landscape-scale projects consist of smaller projects, which should be encouraged as they are easier to conceptualise, fund and deliver; encouraging smaller projects to collaborate so that the beneficial impacts are scaled up; considering the landscape beyond its geographical confines to offer new opportunities for communities and habitats outside the immediate scope of the programme in question; considering trends in ecological and socio-economic systems, including climate change impacts, human migration patterns, changes in land use, etc.; working within a holistic, sustainable development framework; and taking a long-term perspective - generations, decades, centuries.

- Enhance people's lives by creating related employment, building local capacity, improving local quality of life, incorporating local aspirations into a landscape vision and continuing the human narrative of the landscape by engendering a sense of place and reaffirming cultural identity.

A central consideration is that social development programmes too often ignore livelihood possibilities from restoring the natural environment and, similarly, environmentally focussed rehabilitation programmes may not always consider the needs of people when determining final land use options. Landscape restoration should reconcile economic, social and environmental concerns within a holistic framework, with the best projects utilising environmental improvements as drivers for socio-economic regeneration. Less commonly, but more effectively, socio-economic development can be used to generate enduring 
environmental improvements. Such considerations are fundamental to many aspects of the sustainable development paradigm. It is this conceptual context, and the environmental and socio-economic potential that underlies it, that forms the backdrop to the mine closure aspects of this paper.

\subsubsection{Case Study 1: The comprehensive everglades restoration plan, USA}

Florida's Everglades ecosystem is dominated by the retention of water from the rainy season's intense downpours that used to flow southwards as a slow surface sheet flow over the flat topography. In the midtwentieth century, devastating hurricanes led to a public outcry, causing Congress to pass the Central and Southern Florida Project (C\&SF Project) in 1948, mandating the US Army Corps of Engineers (USACE) (federal) and South Florida Water Management District (SFWMD) (state) to construct one the most elaborate water management systems anywhere. Its 1,600 km of levees, 1,160 km of canals and 200 water control structures effectively control flooding, prevent saltwater intrusion, supply water to the Everglades National Park and protect fish and wildlife resources.

The Everglades ecosystem is critical to the society and economy of Florida for supplying freshwater to agriculture and people; supporting valuable freshwater fisheries; attracting tourism for its unique wildlife, wilderness and beaches; and as a backdrop to indigenous peoples' heritage. The annual financial value of these ecosystem services to 9 million people, plus agriculture and industry, has been calculated as US\$ 82.1 billion (Center for Urban and Environmental Solutions, 2009).

Although the C\&SF Project has been highly effective in reducing the impacts of extreme flooding events, it has seriously impacted natural water flows and the ecosystem. Ecosystem services are at risk from slow desiccation leading to increased erosion and soil infertility; invasion by exotic species, leading to ecosystem change and an enhanced fire risk; diminished recharge and seawater intrusion into the aquifers that supply drinking and irrigation water; failing freshwater fisheries; and phosphorus pollution.

The Comprehensive Everglades Restoration Plan (CERP) is a partnership between state (SFWMD) and federal (primarily USACE) institutions and myriad other groups and projects. It provides a framework and guide for restoring, protecting and preserving the water resources over $46,000 \mathrm{~km} 2$ of Florida. USACE's involvement in such projects is very recent and has required changes in institutional perspectives and practices extending to the contractors they employ.

CERP is the world's largest ecosystem restoration programme, costing over US\$ 10 billion over 30 years. It aims to capture most of the 6.5 billion litres of water draining daily to the coast and store it at the surface and in aquifers for human needs (20\%) and ecosystem revival (80\%). Enormous surface water storage structures are in construction, and hydrological connectivity, involving the removal of $390 \mathrm{~km}$ of levees and canals and the bridging of long road sections, is being improved. The restored natural sheet flow will encourage natural vegetation to return. CERP works alongside other projects to control invasive species and restore critical areas, as well as related public engagement and formal education programmes.

According to the Everglades Foundation, investing US\$11.5 billion in Everglades restoration will result in US\$ 46.5 billion in economic gains and create over 440,000 jobs over the next 50 years; for every dollar invested in Everglades restoration, US\$ 4 are generated in economic benefits (Mather Economics, 2010).

\subsubsection{Case Study 2: Dry tropical forest restoration in Area de Conservacion Guanacaste, Costa Rica}

Costa Rica's Area de Conservacion Guanacaste (ACG) possesses about $4 \%$ of the world's biodiversity and is a World Heritage Site, yet only four decades ago this would have seemed an unlikely dream, given the area's intense agricultural and ranching history. In the 1940s the Pan-American Highway was pushed through with the simultaneous introduction of jaragua (Hyparrhenia rufa) pasture grass from East Africa.

ACG is home to one of the world's largest tropical forest restoration projects, largely driven by tropical ecologist Dan Janzen. He realised that the ownership of land needs to be psychologically and socially visible to outsiders if conservation is to work over the long term. This revelation coincided with a severe decline in the national agro-economy, including a fall in cattle production. The removal of cattle in 1978 caused the 
jaragua to grow rapidly, promoting fires that threatened to destroy what little forest remained. In 1985 Janzen and Winnie Hallwachs developed a strategy for conserving and restoring ACG with a novel view of a large, conserved wildland as a 'somewhat disorderly garden, one that is multi-cropped, multitasked and has multiusers, and that produces its crops in unconventional kinds of sacks and boxes' (Janzen, 2000).

Dry forest cannot be restored by simply planting trees, as the key inhibiting factor is fire, exacerbated by human activity and jaragua. Controlling fire limits the spread of jaragua and allows natural tree recolonisation. Much effort was spent employing and equipping local people as firefighters - the same people who had been manipulating fire and vegetation for most of their lives.

Bespoke systems have been developed to employ, educate, train and create sensitive agriculture and tourism infrastructure that support ecological recovery and derive socio-economic benefits from it, based on the philosophy that 'conservation into perpetuity demands the abandonment of the model of society fenced out and passive institutional custody'. The receipt of local benefits fosters local dependence so that local people become motivated to act in sympathy to conservation objectives (Janzen, 2000).

The ACG team recognised early on that conservation was at least as much social as it was natural and that the solution had to be 'conservation through non-damaging use' (D. Janzen, Oct. 2011, pers. comm.). ACG's restored landscape is now a mosaic of forest successional stages on 6,000 ha of former pasturelands. This scale offers many opportunities for research and innovative practice relating to biodiversity recovery and conservation, natural resource management, sensitive economic development and social justice.

The politics and administration of ACG has been a journey of constituency-building to develop a bespoke system of decentralised governance at odds with the conventional centralised and hierarchical structures. Originally the diversity of land designations and ownerships that became joined to form ACG each had their own formal owners and multiple administrations. These interests were eventually united under a central administrative structure as a non-governmental/ governmental hybrid to manage ACG. Today ACG manages $2 \%$ of Costa Rica at almost no cost to taxpayers and has helped foster Costa Rica's international reputation for progressive environmental stewardship and its ecotourism industry - the country's biggest earner.

\subsubsection{Case Study 3: Tropical island restoration, Galapagos Islands, Ecuador}

The ecology of the Galapagos Islands has stimulated ever-increasing numbers of tourists, simultaneously increasing pressures on the ecology they have come to see. The islands are Ecuador's wealthiest region, due to the tourism boom, hence the rapid influx of mainland Ecuadorians. As tourism grows, so do development pressures for land and water resources and the impacts from increasing waste and boat and air traffic. A major threat comes with approximately 1,500 introduced/ non-native/ alien species over the past 40 years. A major research and control effort is under way, as it is realised that alien species could undermine the ecological economic foundation of the islands (Gardener and Grenier, 2011).

Research by the Charles Darwin Foundation (CDF) shows that it is probably not possible, nor even desirable, to convert the inhabited islands back to a pristine state - a controversial perspective that challenges conventional thinking. Cultural and socio-economic drivers are also important and must be factored into the islands' restoration efforts. Despite the relatively pristine nature of Galapagos biodiversity compared with other island systems, the ecological impact of invasive and introduced plant species is probably too advanced to reverse completely with current technology; between 2001 and 2007 CDF carried out 29 plant eradication projects on 23 invasive species, focussing on those still limited to small areas. Only four of the projects succeeded in eradication and none were over 1 ha. The conclusion, given current and likely future resources: eradicating invasive plants is a practical impossibility (M. Gardener, Nov. 2011, pers. comm.). Furthermore, there are so many different invasive species and ecological impacts that the removal of one species is likely to result in replacement by another invasive.

There is a more pragmatic but controversial perspective in which the goal is to maintain as much native biodiversity as possible, together with the original functionality, and to undertake management that maximises benefits over the total area of intervention and not focus solely on invasive species. Here the 
pre-human state is unattainable, given realistically available resources. Such hybrid and novel ecosystems those that have new species combinations arising through either species invasions or environmental change - are now widespread and could become objects of conservation for their own sake. This approach frees up resources for the conservation of important native species in areas less impacted by exotics and still allows for meeting basic cultural and socio-economic needs.

\subsubsection{Case Study 4: Farmland restoration in Patagonia, Chile}

During the late nineteenth and early twentieth centuries, thousands of settlers arrived in Chilean Patagonia - encouraged by government programmes to 'clean' the land to gain title, while loggers removed timber and farmers razed millions of forested hectares. Extreme rainfall, steep slopes, unprotected thin soils and poor farming practices caused catastrophic soil erosion and poor-quality pasture, resulting in single farms covering huge areas just to graze sufficient livestock to make a viable economic return. By the late twentieth century, much of the region's agriculture had collapsed. Reforestation with exotic tree species was encouraged in the 1970s, preventing natural re-colonisation by the forest. In the 1980s a road was driven through the region, improving access for people wanting land, leading to further deforestation.

The Patagonian work of conservation philanthropists Doug and Kris Tompkins provides an inspiration for innovative approaches to restoring and conserving damaged lands while simultaneously developing new livelihoods. They have ensured the protection and restoration of a million hectares of Patagonia. Acquiring and restoring strategically located, degraded valley farms with their extensive forested mountain slopes has enabled the protection of much greater areas by connecting existing protected areas and creating new ones. This is how the $3,250 \mathrm{~km} 2$ Pumalin Park was created in a process lasting over 20 years. The restored farms are the focal points for developing a new regional economy based on conservation, tourism and responsible farming. The innovation has been in developing multi-use and organic farms to simultaneously act as park stations that house park rangers, visitor centres, accommodation providers and native plant nurseries and to research and improve animal husbandry (mainly sheep) and related (mainly wool) products, to produce fruit and vegetables for by visitors or for local sale, to employ local people and to produce honey and jams from locally grown fruit. This new farming model is being developed through trial and error. The important message is the demonstration of a new farming model that recognises the region's geographic limitations (and opportunities).

A Pumalin Park team is working with El Amarillo village to enhance its appearance and stimulate 'house pride' by improving buildings, gardens, public spaces and infrastructure. The team of architects, designers and builders collaborates with local homeowners in subsidising the exterior renovation of their homes and helping with landscaping, fences and painting. The park is also upgrading the village's public spaces in line with the spectacular surrounding natural geography. The team does not yet know if this approach will work, but the response from locals so far has been enthusiastic, and community pride appears to be building. The project will finish by 2015 , after which it is hoped that the community will be more attractive to residents and visitors and provide a fitting new visitor gateway to Pumalin Park.

The Tompkins' ultimate aim is to 'play the tourism card, which is a way to diversity the local economy and reduced dependence on forestry and farming on unsuitable land' (D. Tompkins, Dec. 2011, pers. comm.). A new regional economy is developing based on the conservation of wild areas, environmentally sensitive tourism and responsible farming practices.

Over many years, analysis of a broad range of both mining and non-mining landscape restoration projects across the world in a great diversity of environments and jurisdictions has enabled the identification of common challenges and approaches for overcoming them. The challenges to good practice and the means to overcome them are summarised here under the themes participation, governance, sustainability and 'the Oil in the Machine'. These elements and themes, which are not mutually exclusive, are introduced in Table 1 and expanded as summary recommendations in Tables 2-5. Each of these themes could be incorporated into mine closure planning in the future, to enable the plan to become a meaningful, coherent and self-contained document that describes a fully integrated closure process. 
Table 1 Common challenges in mine closure and landscape restoration projects

\begin{tabular}{|c|c|c|c|}
\hline Participation & Governance & Sustainability & $\begin{array}{l}\text { 'The Oil In The } \\
\text { Machine' }\end{array}$ \\
\hline Local communities & Controlling the land & Empowerment and & Leadership \\
\hline Constituency building & Funding & capacity building & Communication \\
\hline \multirow[t]{4}{*}{ Changing perceptions } & Project goals & Scaling & Collaboration \\
\hline & Institutional barriers & Alien species & Knowledge \\
\hline & Policy and legislation & Reinventing the wheel & Creativity and beauty \\
\hline & & & Culture \\
\hline
\end{tabular}

\subsection{Participation}

Meaningful stakeholder participation leads to more-informed restoration activities, justifying the additional time and resources required in ensuring greater participation. Essential participants are the mining company and communities and the stakeholders local to the project, as the greater the degree of participation, the greater the sense of ownership. However, there may also be a requirement for upfront investment in capacity building in the short term. Key elements of successful participation are outlined in Table 2. Not engaging local communities should not be an option, but it is not always easy; they may be isolated geographically and independently minded, or they may have been previously overlooked or blamed for environmental damage to satisfy pressing needs when the wider society offered no alternative. They may feel disenfranchised, apathetic, insular, independent and wary of outsiders. Poor previous consultation experiences persist in the collective memory, leading to distrust and a lack of constructive engagement. Cultural and language differences and poor education can be further barriers to engagement and may be compounded by a lack of capacity. Such communities are not uncommon in degraded lands.

\section{Table 2 Summary recommendations for addressing project participation challenges}

\begin{tabular}{|c|c|c|}
\hline Local Communities & Constituency Building & Changing Perceptions \\
\hline $\begin{array}{l}\text { Make a genuine, high-level commitment to } \\
\text { engage }\end{array}$ & $\begin{array}{l}\text { Take time to understand local } \\
\text { politics and vested interests }\end{array}$ & \multirow{2}{*}{$\begin{array}{l}\text { Positive personal relationships are } \\
\text { the foundation for persuading } \\
\text { others to believe in an alternative } \\
\text { way of behaving }\end{array}$} \\
\hline $\begin{array}{l}\text { Engage early in a neutral space or on the } \\
\text { community's terms }\end{array}$ & $\begin{array}{l}\text { Spare no effort in engaging } \\
\text { influential stakeholders, particularly }\end{array}$ & \\
\hline Communicate openly with free, prior & during early project phases & \multirow{4}{*}{$\begin{array}{l}\text { Physical demonstration is } \\
\text { essential, particularly in early } \\
\text { project stages } \\
\text { Create new employment } \\
\text { opportunities related to the land }\end{array}$} \\
\hline informed consent & Make full use of the media & \\
\hline $\begin{array}{l}\text { Make information freely accessible } \\
\text { (physically, intellectually, linguistically) }\end{array}$ & $\begin{array}{l}\text { Encourage others to sing your } \\
\text { praises }\end{array}$ & \\
\hline Give sufficient time to relationship building & Keep communication channels open & \\
\hline Research the needs and structures that & & $\begin{array}{l}\text { Facilitate opportunities for further } \\
\text { personal development }\end{array}$ \\
\hline $\begin{array}{l}\text { Involve the community in setting the } \\
\text { restoration agenda }\end{array}$ & $\begin{array}{l}\text { Share success by crediting others for } \\
\text { their support and involvement }\end{array}$ & \multirow{6}{*}{$\begin{array}{l}\text { Sharing the credit builds wider } \\
\text { appreciation in your effort and } \\
\text { reflects the actual collaborative } \\
\text { nature of the achievement }\end{array}$} \\
\hline Identify local champions & & \\
\hline $\begin{array}{l}\text { Devote early effort to ensuring a } \\
\text { community can ask the right questions }\end{array}$ & & \\
\hline $\begin{array}{l}\text { See opportunities for developing } \\
\text { transferable skills and knowledge }\end{array}$ & & \\
\hline $\begin{array}{l}\text { Commission a third party to broker a } \\
\text { solution if conflict arises }\end{array}$ & & \\
\hline $\begin{array}{l}\text { Employ creative and participatory } \\
\text { approaches }\end{array}$ & & \\
\hline
\end{tabular}




\subsection{Governance}

Paying attention to the details of how the closure project and its aftermath are governed can greatly improve outcomes and attract further funding and in-kind contributions, leading to greater project sustainability. Good governance ensures that long-term project viability goes beyond simply restoring and walking away and is essential for delivering long-term socio-economic benefits. In this sense, good governance includes clear decision making, financial/ fiduciary responsibilities, efficient administration and transparency (Table 3). Decision making should be guided by principles established from the outset. Critically, the governing body should facilitate the regular monitoring and evaluation of project activities, ensuring that quality is maintained and funds are spent wisely.

\section{Table 3 Summary recommendations for addressing project governance challenges}

\begin{tabular}{|c|c|c|c|c|}
\hline $\begin{array}{l}\text { Controlling the } \\
\text { Land }\end{array}$ & Funding & Project Goals & $\begin{array}{l}\text { Institutional } \\
\text { Barriers }\end{array}$ & $\begin{array}{l}\text { Policy and } \\
\text { Legislation }\end{array}$ \\
\hline $\begin{array}{l}\text { Buy or lease the } \\
\text { land or enter into } \\
\text { land management } \\
\text { agreements } \\
\text { Generate visible } \\
\text { activities that } \\
\text { signal the land is } \\
\text { used and providing } \\
\text { benefit } \\
\text { Create a single, } \\
\text { representative, } \\
\text { accountable body } \\
\text { to control } \\
\text { restoration } \\
\text { activities } \\
\text { If necessary, } \\
\text { support this body } \\
\text { with a legal } \\
\text { mandate } \\
\text { Be clear about } \\
\text { existing liabilities }\end{array}$ & $\begin{array}{l}\text { Develop creative } \\
\text { fundraising } \\
\text { approaches by being } \\
\text { flexible with } \\
\text { objectives } \\
\text { Employ experienced } \\
\text { fundraisers with } \\
\text { local knowledge } \\
\text { Note the wider } \\
\text { project contexts, } \\
\text { integral to success } \\
\text { Develop funding } \\
\text { plans to leverage } \\
\text { funds from existing } \\
\text { stakeholder plans } \\
\text { Pursue a range of } \\
\text { sources for } \\
\text { consistency over } \\
\text { time } \\
\text { Develop } \\
\text { independent, } \\
\text { autonomous funding } \\
\text { Tap into smaller } \\
\text { grants for specific } \\
\text { aspects of larger } \\
\text { programmes } \\
\text { Consider in-kind } \\
\text { contributions } \\
\text { Use the project to } \\
\text { stimulate other } \\
\text { socio-economic } \\
\text { activities } \\
\text { Pursue payment for }\end{array}$ & $\begin{array}{l}\text { Give sufficient time to } \\
\text { building goals and } \\
\text { collaboration } \\
\text { When setting project } \\
\text { goals, ask: } \\
\text { - What is the } \\
\text { restoration } \\
\text { starting point? } \\
\text { - What is the } \\
\text { project aiming to } \\
\text { restore to? } \\
\text { - How will this } \\
\text { point be } \\
\text { recognised? } \\
\text { - Whom is it for? } \\
\text { - Who determines } \\
\text { project goals? } \\
\text { What livelihood } \\
\text { opportunities are } \\
\text { possible? } \\
\text { - What are the } \\
\text { cultural } \\
\text { opportunities? } \\
\text { Who determines } \\
\text { the correct } \\
\text { approach? } \\
\text { Divide ambitious } \\
\text { soals into smaller } \\
\text { each accordingly } \\
\text { potential clashes? }\end{array}$ & $\begin{array}{l}\text { Work with } \\
\text { relevant } \\
\text { stakeholders to } \\
\text { identify } \\
\text { important } \\
\text { institutional } \\
\text { barriers } \\
\text { When identified, } \\
\text { allocate a small } \\
\text { team to focus on } \\
\text { surmounting it } \\
\text { Create project } \\
\text { teams that cut } \\
\text { across } \\
\text { institutional } \\
\text { boundaries } \\
\text { Develop } \\
\text { personal } \\
\text { relationships } \\
\text { between } \\
\text { institutions } \\
\text { Consider a } \\
\text { bespoke system } \\
\text { of decentralised } \\
\text { governance for } \\
\text { land } \\
\text { management }\end{array}$ & $\begin{array}{l}\text { Build influence } \\
\text { with policy } \\
\text { advisors and } \\
\text { makers through } \\
\text { strong personal } \\
\text { relationships } \\
\text { Communicate } \\
\text { regularly, } \\
\text { honestly and } \\
\text { inclusively } \\
\text { If necessary, } \\
\text { give } \\
\text { government an } \\
\text { element of } \\
\text { control to assist } \\
\text { project aims } \\
\text { Use pilot } \\
\text { projects to } \\
\text { demonstrate } \\
\text { success and } \\
\text { show how it can } \\
\text { deliver existing } \\
\text { policy and } \\
\text { regulatory aims } \\
\text { Apply well- } \\
\text { informed and } \\
\text { appropriately } \\
\text { targeted } \\
\text { external } \\
\text { pressure and } \\
\text { lobbying to } \\
\text { influence } \\
\text { policies }\end{array}$ \\
\hline
\end{tabular}




\subsection{Sustainability}

A key challenge faced by any mining community, and the crux of the mining and sustainable development debate, is how to convert values from the mine's finite natural resource into long-term community benefits that persist beyond closure. The nexus of that challenge arrives when a mine closes, at which point it is too late to consider implementing meaningful community development programmes. As with progressive restoration during the operational phase, a well-considered community development programme during the mine life will ease the path to closure, lessening the impacts when the day finally arrives.

The advent of closure should preface a smooth transition between mining and post-mining for stakeholder and local community participation and project governance, rather than necessitate the need to initiate these, or deliver wholesale changes in a forced time frame. This would include incorporating changes to governing bodies to increase stakeholder participation over time and developing funding and project management and delivery mechanisms that can persist without support from the company. Increasing stakeholder participation over time may also require investment in capacity building prior to a formal handover of the project to new 'owners'. Evidently, such planning for closure is required well in advance of the event actually happening and, ideally, should be an objective from the start, pending any unforeseen closure event. Recommendations for overcoming the sustainability challenges are summarised in Table 4.

Table 4 Summary recommendations for addressing project sustainability challenges

\section{Empowerment and Capacity Building}

Note that good interpersonal skills are essential

Employ locally wherever possible

Properly resource education and training to address knowledge gaps

Second staff from collaborating organisations to build mutual understanding

Use staff to train other staff, creating professional bonds and organisational understanding

Be aware that volunteers can be invaluable and also problematic

Scaling

Alien Species

Encourage smaller projects Objectively consider the to develop within the broader programme, as they can be more intellectually and physically accessible to ordinary people

Use a multi-disciplinary and collaborative approach to restore ecosystem services Collaborate with similar projects in the same area or in the same ecosystem

Connect with neighbouring landscapes and communities to encourage spill-over benefits

Work with government to deliver their sustainable development objectives Implement succession planning to build an intergenerational project and enhance scaling in time risk from alien species

Determine if any are used by local people

Determine whether natural control is possible Control them if this can be done cheaply and without irreversible environmental damage

Consider funding biocontrol research if other control measures prove inadequate

Implement quarantine procedures, if feasible If little alternative, protect and restore degraded areas where feasible and manage the most heavily infested areas

Ensure staff receive adequate training on managing the threat Collaborate with others with similar challenges
From the outset, task individuals to similar research projects elsewhere

Contact individuals involved in these projects

Encourage an organisational mentality of assisting others Record the processes of your project for use by others and include:

- How the project was conceived and implemented

- Who did what

- Particular challenges and how they were overcome

- The outcomes and how success was measured

Make such information freely available and widely disseminated

Use this information to promote the project, build trust and improve practice elsewhere 


\subsection{The oil in the machine}

Delivering a good-practice closure project needs to be about much more than ticking a checklist of stages and processes; it is an organic thing built on human relationships and evolving over years/ decades with changing personal circumstances, societal expectations and personalities. Inevitably, unpredictable events and opportunities occur that will need to be carefully considered and reacted to. The more flexibility and adaptability engrained in a project's modus operandi and collective philosophy, the more durable and ultimately successful it will be. There are several cross-cutting themes that are critical to every successful project everywhere, called here, for want of a better term, 'the oil in the machine'. The key elements of it are leadership, communication, collaboration and knowledge (Table 5). 
Table 5 Summary recommendations for addressing cross-cutting 'oil in the machine' challenges

\begin{tabular}{|c|c|c|c|c|c|}
\hline Leadership & Communication & Collaboration & Knowledge & Creativity and Beauty & Culture \\
\hline $\begin{array}{l}\text { Respected leaders are } \\
\text { essential, but not easy to } \\
\text { find } \\
\text { The leader should be a } \\
\text { competent, confident media } \\
\text { performer } \\
\text { The leader may be self- } \\
\text { selecting, having driven the } \\
\text { project from a dream to } \\
\text { reality - an adaptable and } \\
\text { supportive team will be } \\
\text { indispensable to managing } \\
\text { the leader's negative } \\
\text { attributes } \\
\text { Succession planning is } \\
\text { essential, especially for } \\
\text { projects over long time } \\
\text { frames } \\
\text { A single organisation should } \\
\text { run the project and, ideally, } \\
\text { be the same one that } \\
\text { controls the land } \\
\text { Don't let the organisation } \\
\text { dilute the visibility of the } \\
\text { leading person } \\
\text { In-fighting can be diffused by } \\
\text { strong leadership and agreed } \\
\text { roles and responsibilities } \\
\text { within the project delivery } \\
\text { programme }\end{array}$ & $\begin{array}{l}\text { Develop clear and easily } \\
\text { understandable project } \\
\text { objectives } \\
\text { From the start, use a range } \\
\text { of visual tools, particularly } \\
\text { demonstration models, to } \\
\text { showcase project plans } \\
\text { Invite constructive feedback } \\
\text { and adapt plans as necessary } \\
\text { Make full and creative use of } \\
\text { all the communication } \\
\text { opportunities available } \\
\text { Be accessible and } \\
\text { transparent } \\
\text { Build communication with } \\
\text { projects in similar } \\
\text { ecosystems elsewhere to } \\
\text { share knowledge and build } \\
\text { public awareness more } \\
\text { broadly } \\
\text { Establish forums with } \\
\text { stakeholders and local } \\
\text { communities and meet } \\
\text { regularly }\end{array}$ & $\begin{array}{l}\text { Begin relationship building } \\
\text { early in the planning process } \\
\text { Allow sufficient time for } \\
\text { building personal relationships } \\
\text { within and between } \\
\text { institutions } \\
\text { Develop a common agenda } \\
\text { and goals that encompass the } \\
\text { disparate motivations } \\
\text { Incentivise collaborative } \\
\text { legislation and catalytic } \\
\text { funding } \\
\text { Include representation from all } \\
\text { relevant parties } \\
\text { Move forward on a consensus } \\
\text { basis, if possible } \\
\text { Involve technical experts who } \\
\text { can give candid and regular } \\
\text { advice } \\
\text { Ensure that 'champions' for } \\
\text { particular issues are respected } \\
\text { within their realm of influence } \\
\text { Give equal voice to groups } \\
\text { with different yet valid } \\
\text { perspectives } \\
\text { Develop shared understanding } \\
\text { of project challenges and } \\
\text { approach } \\
\text { Progress on the ground is key } \\
\text { to building mutual } \\
\text { understanding and trust } \\
\text { Continuity of project team } \\
\text { staffing - succession planning } \\
\text { and smooth transitions }\end{array}$ & $\begin{array}{l}\text { Record and publicise the } \\
\text { project story } \\
\text { Basic early research may be } \\
\text { sufficient to inform closure/ } \\
\text { restoration activities (be } \\
\text { wary of increasing costs and } \\
\text { time by striving for } \\
\text { unnecessary perfection) } \\
\text { Focus detailed research on: } \\
\text { project compromising } \\
\text { challenges, improving } \\
\text { efficiency, responding to } \\
\text { changing local circumstances } \\
\text { Research need not be } \\
\text { academically orientated, but } \\
\text { must produce useful results } \\
\text { on which judgements can be } \\
\text { made } \\
\text { Collaborate to assist } \\
\text { research, monitoring and } \\
\text { education and training } \\
\text { Commission research on } \\
\text { potential socio-economic } \\
\text { and cultural impacts to assist } \\
\text { lobbying activities } \\
\text { Monitor socio-economic and } \\
\text { cultural indicators, as well as } \\
\text { ecological ones, during the } \\
\text { project and afterwards } \\
\text { Alter perspectives to include } \\
\text { long-term education and } \\
\text { training opportunities } \\
\text { alongside ecological } \\
\text { concerns }\end{array}$ & $\begin{array}{l}\text { Employ artists to contribute } \\
\text { to designs and planning } \\
\text { Encourage staff to develop a } \\
\text { creative edge to their } \\
\text { thinking and work } \\
\text { Use creative approaches to } \\
\text { engage audiences - offer an } \\
\text { emotional experience } \\
\text { Enhance and market the } \\
\text { creative aspects of the local } \\
\text { landscape and communities } \\
\text { - work to enhance local } \\
\text { culture to encourage local } \\
\text { community participation and } \\
\text { enhance socio-economic } \\
\text { opportunities } \\
\text { Strive for beauty }\end{array}$ & $\begin{array}{l}\text { View the restoration project } \\
\text { as a new chapter in the } \\
\text { landscape narrative } \\
\text { Ensure that the cultural } \\
\text { history and traditions of the } \\
\text { landscape and its } \\
\text { communities are properly } \\
\text { researched and understood } \\
\text { by the project team } \\
\text { Develop restoration activities } \\
\text { that enhance local traditions } \\
\text { and practices that explore } \\
\text { potential socio-economic } \\
\text { benefits }\end{array}$ \\
\hline
\end{tabular}




\section{$4 \quad$ Conclusions}

All mining operations are unique responses to their geological, political, economic, social and environmental contexts; consequently, all mine closure projects are unique too - there is no standard formula or checklist for delivering them. Although closure practice is advancing, improvements are slow and patchy. And despite the good-practice regulation, standards and guidance available, many mine closure projects fall short in delivering on the expectation that future public health and safety are not compromised, that the after-use of the site is beneficial and sustainable to the affected communities in the long term and that adverse socio-economic impacts are minimised and socio-economic benefits maximised.

Each of the four generic limitations to mine closure planning and practice outlined in Section 2 have been addressed by considering the recommendations derived from analysing non-mining landscape restoration projects. They illustrate the key point that despite the differences in disciplines, sectors and institutional barriers, most if not all the lessons are transferable. Mining stakeholders need to apply 'outside the mine' thinking - that is, considering the environmental and socio-economic opportunities beyond a mine's immediate environs and what relevant knowledge can be garnered from others in the mining sector and, critically, beyond it. The power of inspiring change in attitudes and approaches through the promotion of successful examples and, ideally, by learning from the places and people involved - for all actors in the mine closure debate - should not be underestimated.

There needs to be a shift in the conventional paradigm in all stakeholders from perceiving mines as problems to seeing them as opportunities for communities and the environment. This thinking needs to begin at the outset of mine planning - designing and mining for closure - to ensure that future environmental and community opportunities are built into the mine's fabric and corporate mindset. Ideally, mines should be planned, developed and operated as if they are closure projects from the outset (Peck, 2005). The suggested changes in approach will require engaging with appropriate experts - maybe artists, historians, landscape restoration experts, horticulturalists, wildlife experts, entrepreneurs, etc. - people with knowledge of a range of successful approaches in different circumstances.

Change is required in the conventional template to which most mine closure plans are produced. The plan should outline the strategy that creates the foundation upon which to build a new environmental and socio-economic future for the surrounding communities. Too often this is not the case. What is needed is a re-think on how these plans are written, with modified guidance to encourage a more progressive approach towards the potential opportunities arising from the closure. As much detail should be provided on the participation, governance, sustainability and 'oil in the machine' issues as on the technical reclamation aspects. They should be written as stand-alone documents in which the mine's community development plan becomes integral by considering community development in a similar vein to 'progressive restoration'.

A mine and its people and context can only ever be a chapter in the narrative of a landscape. It is incumbent on those connected with the mining industry to ensure that the end of a mine signals the start of a new chapter and not the end of the story.

\section{References}

Anglo American (2013) Mine Closure Planning, viewed July 2013, http://www.angloamerican.com/development/mine-closureplanning/approach.

Australian Government (2006a) Mine Closure and Completion, Leading Practice Sustainable Development Programme for the Mining Industry, Department of Industry, Tourism and Resources.

Australian Government (2006b) Mine Rehabilitation, Leading Practice Sustainable Development Programme for the Mining Industry, Department of Industry, Tourism and Resources.

Bai, Z.G., Dent, D.L., Olsson, L. and Schaepman, M.E. (2008) Proxy global assessment of land degradation: review article, Soil Use and Management, Vol. 24, pp. 223-234.

Center for Urban and Environmental Solutions at Florida Atlantic University (2009) The Economics of the Everglades Watershed and Estuaries, prepared for the Everglades Foundation. 
EBRD (European Bank for Reconstruction and Development) (2008) Environmental and Social Policy (including Performance Requirements).

Equator Principles (2006) http://www.equator-principles.com.

EU (European Union) (2006) EU Directive 2006/21/EC of the European Parliament and the Council of 15 March 2006 on the management of waste form the extractive industries and the amending Directive 2004/35/EC, published in the Official Journal of the European Union, 11 April 2006 (L102/15).

EU (European Union) (2009) Reference Document on Best Available Techniques for Management of Tailings and Waste-Rock in Mining Activities, European Commission, Brussels.

Gardener, M.R. and Grenier, C. (2011) Linking livelihoods and conservation: challenges facing the Galapagos Islands, in Islands Futures: Conservation and Development across the Asia-Pacific Region. Springer, Chapter 6.

Hobbs, R.J. and Harris, J.A. (2001) Restoration ecology: repairing the earth's ecosystems in the new millennium, Restoration Ecology, Vol. 9(2), pp. 239-246.

Hobbs, R.J. and Norton, D.A. (1996) Towards a conceptual framework for restoration ecology, Restoration Ecology, Vol. 4(2), pp. 93-110.

ICMM (International Council on Mining and Metals) (2006) Guidance Paper: Financial Assurance for Mine Closure and Reclamation, London.

ICMM (International Council on Mining and Metals) (2008) Planning for Integrated Mine Closure: Toolkit, London.

IFC (International Finance Corporation) (2012a) Performance Standards on Environmental and Social Sustainability, Washington, DC.

IFC (International Finance Corporation) (2012b) Performance Standards on Environmental and Social Sustainability: Guidance Notes, Washington, DC.

Janzen, D.H. (2000) Costa Rica's Area de Conservacion Guanacaste: a long march to survival through non-damaging biodiversity and ecosystem development, in Norway/ UN Conference on the Ecosystem Approach for Sustainable Use of Biological Diversity, Norwegian Directorate for Nature Research and Norwegian Institute for Nature Research, Trondheim, Norway, pp. 122-132.

Keith, D.A., Rodríguez, J.P., Rodríguez-Clark, K.M., Nicholson, E., Aapala, K., Alonso, A., Asmussen, M., Bachman, S., Basset, A., Barrow, E.G., Benson, J.S., Bishop, M.J., Bonifacio, R., Brooks, T.M., Burgman, M.A., Comer, P., Comín, F.A., Essl, F., Faber-Langendoen, D., Fairweather, P.G., Holdaway, R.J., Jennings, M., Kingsford, R.T., Lester, R.E., Mac Nally, R., McCarthy, M.A., Moat, J., Oliveira-Miranda M.A., Pisanu, P., Poulin, B., Regan, T.J., Riecken, U., Spalding, M.D. and ZambranoMartínez, S. (2013) Scientific foundations for an IUCN Red List of ecosystems, PLoS ONE, Vol. 8(5): e62111.

Kulkarni, S.C., Levin-Rector, A., Ezzati, M. and Murray, C. (2011) Falling behind: life expectancy in US counties from 2000 to 2007 in an international context, Population Health Metrics, Vol. 9(16).

Lindberg, T.T., Bernhardt, E.S., Bier, R., Helton, A.M., Merola, R.B., Vengosh, A. and Di Guilo, R.T. (2011) Cumulative impacts of mountaintop mining on an Appalachian watershed, in Proceedings of the National Academy of Sciences, Vol. 108(52), pp. 20, 929-20,934.

Maginnis, S. and Jackson, W. (2007) What is FLR and how does it differ from current approaches? in The Forest Landscape Restoration Handbook, J. Rietbergen-McCracken, S. Maginnis and A. Sarre (eds), Earthscan, London.

Mather Economics (2010) Measuring the Economic Benefits of America's Everglades Restoration, prepared for the Everglades Foundation.

Millennium Ecosystem Assessment, Living Beyond Our Means: Natural Assets and Human Well-Being, Island Press, Washington, DC.

Nkonya, E., Gerber, N., von Braun, J. and de Pinto, A. (2011) Economics of Land Degradation. The Costs of Action Versus Inaction, Issue Brief 68, Center for Development Research, International Food Policy Research Institute, Washington, DC.

Peck, P. (2005) Mining for Closure: policies, practices and guidelines for sustainable mining practices and closure of mines, ENVSEC, UNEP, UNDP, OSCE, NATO.

Rio Tinto (2013) Closure Standard, viewed 29 July, http://www.riotinto.com/documents/Library/Closure_Standard_EN.pdf.

SER (Society for Ecological Restoration International) (2004) Primer on Ecological Restoration, Version 2.

Whitbread-Abrutat, P.H. (2008) Mining Legacy Survey (for the ICMM-IUCN Dialogue on Mining and Biodiversity), Post-Mining Alliance, Eden Project, Cornwall, UK.

Whitbread-Abrutat, P.H. (2012) Exploring World Class Landscape Restoration, Travelling Fellowship Report, Winston Churchill Memorial Trust, unpublished, available at http://www.petewa.blogspot.com.

World Bank (2011) Sharing Mining Benefits in Developing Countries, Washington, DC.

World Bank Group (2007a) Environmental, Health and Safety Guidelines for Mining, Washington, DC, http://www.ifc.org.

World Bank Group (2007b) Environmental, Health and Safety General Guidelines, Washington, DC, http://www.ifc.org. 
